\title{
Knowledge about standard precautions among university hospital nurses in the United Arab Emirates
}

\author{
J. Sreedharan, 'J. Muttappillymyalil' and M. Venkatramana ${ }^{2}$
}

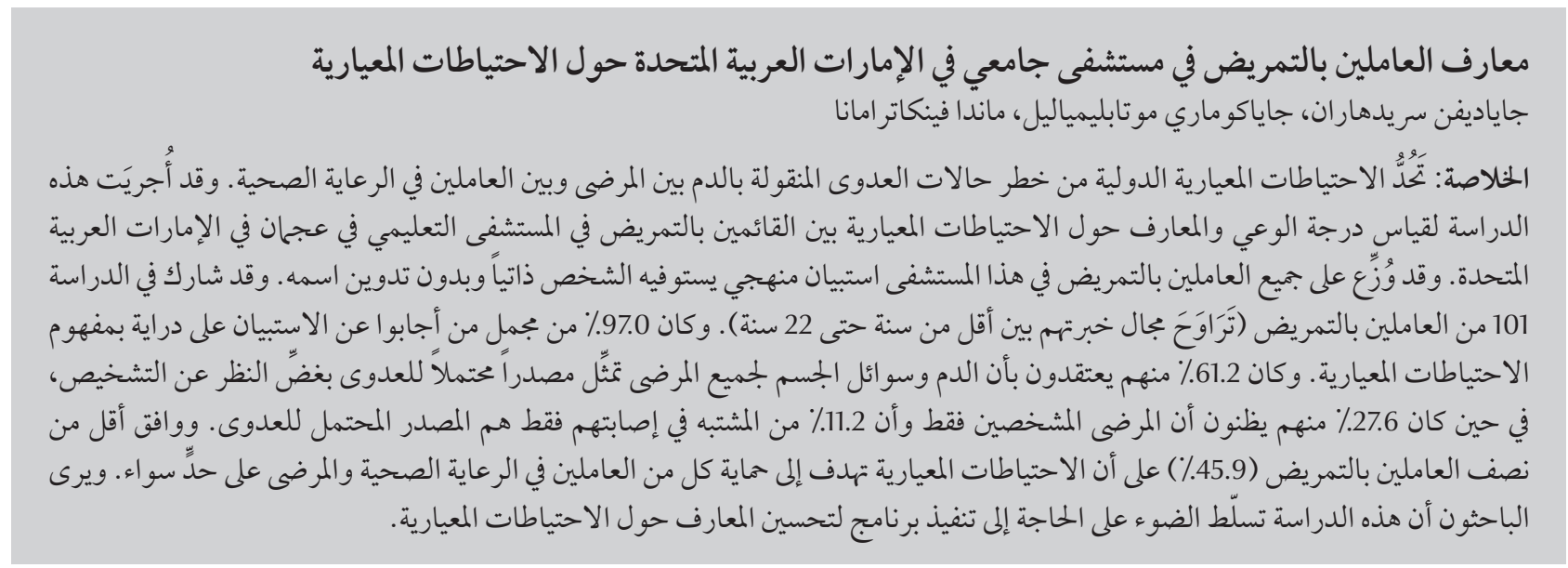

ABSTRACT Standard/universal precautions reduce the risk of transmission of bloodborne infections among patients and health care workers. This study was conducted to assess the awareness and knowledge of standard precautions among nurses in a university teaching hospital in Ajman, United Arab Emirates. All nurses working in the hospital were given a structured, self-administered, anonymous questionnaire: 101 nurses participated (range of experience from $<1$ to 22 years). Overall $97.0 \%$ of respondents were familiar with the concept of standard precautions. Of these $61.2 \%$ believed that the blood and body fluids of all patients are potentially infectious irrespective of their diagnostic status, while $27.6 \%$ thought only diagnosed patients and $11.2 \%$ only suspected cases are potentially infectious. Less than half agreed that standard precautions aimed to protect both health care workers as well as patients (45.9\%). The study highlights a need to implement a programme to improve knowledge on standard precautions.

Connaissance des précautions standard chez le personnel infirmier d'un hôpital universitaire aux Émirats arabes unis

RÉSUMÉ Les précautions standard/universelles réduisent le risque de transmission d'infections véhiculées par le sang chez les patients et les agents de santé. La présente étude a été conduite pour évaluer la sensibilisation du personnel infirmier de I'hôpital universitaire d'Ajman (Émirats arabes unis) aux précautions standard et ses connaissances en la matière. L'ensemble du personnel infirmier a reçu un auto-questionnaire structuré et anonyme, et 101 d'entre eux (dont l'expérience allait de moins d'un an à 22 ans) ont participé à l'étude. Globalement, 97,0 \% des répondants connaissaient bien le concept des précautions standard. Parmi ceux-ci, $61,2 \%$ pensaient que le sang et les liquides organiques de tous les patients étaient potentiellement infectieux quel que soit le diagnostic, alors que $27,6 \%$ croyaient que seuls les patients ayant reçu un diagnostic d'infection étaient potentiellement infectieux et 11,2\% considéraient que les cas suspects uniquement présentaient un risque d'infection. Moins de la moitié d'entre eux (45,9\%) était d'accord sur le fait que les précautions standard étaient destinées à protéger à la fois les agents de santé et les patients. La présente étude souligne le besoin de mettre en œuvre un programme d'amélioration des connaissances sur les précautions standard.

${ }^{7}$ Research Division; ${ }^{2}$ Department of Surgery, Gulf Medical University, Ajman, United Arab Emirates (Correspondence to J. Sreedharan: jayadevans@rediffmail.com/jayadevans@hotmail.com).

Received: 16/06/09; accepted: 05/10/09 


\section{Introduction}

Health care workers (HCWs) are at risk of various occupational hazards in the hospital, including exposure to bloodborne infections such as HIV and hepatitis $\mathrm{B}$ and $\mathrm{C}$ virus ( $\mathrm{HBV}$ and $\mathrm{HCV}$ ) infection from sharps injuries and contact with body fluids [1-3]. Developing countries, which account for the highest prevalence of HIV-infected patients in the world, also record the highest rate of needle-stick injuries [4]. The World Health Organization estimates that about $2.5 \%$ of HIV cases and $40 \%$ of HBV and HCV cases among HCWs worldwide are the result of these exposures [5]. The risk of seroconversion following a needle-stick injury from an HCV-antigen-positive patient is estimated to range from $1.2 \%$ to $10 \%$ [6] and, as there is no immunization currently available for HIV and HCV infection, it is therefore important to prevent infection by preventing exposure to infection.

Standard or universal precautions are a set of measures formulated to prevent transmission of bloodborne pathogens when providing health care. Since identification of patients infected with these pathogens cannot be reliably made by medical history and physical examination, the Centers for Disease Control (CDC) has recommended that standard precautions be used on all patients, regardless of knowledge about their infection status [7]. Compliance with standard precautions has been shown to reduce the risk of exposure to blood and body fluids [8]. Gershon et al. observed that better knowledge of universal precautions among HCWs was one of the correlates of good compliance [9]. Michalsen et al. observed the same among physicians [10].

Knowledge of standard precautions by HCWs may be influenced by their type of training [9,11-13]. Nurses are faced with professional hazards such as needle-stick injuries and bloodborne infections in their day-to-day activities in the work place. Jeong et al. in Korea observed that nurses who were working in the operating room need training to increase their compliance with standard precautions [14]. Awareness about standard precautions among HCWs in Ajman, United Arab Emirates (UAE) has not been assessed before. This study therefore aimed to assess the knowledge about standard precautions among nurses in a teaching hospital in Ajman.

\section{Methods}

This cross-sectional study was conducted from February to May 2009 among nurses involved in virtually every aspect of nursing duties in the Gulf Medical College hospital, Ajman, UAE. This is a 110-bed teaching hospital involved in both undergraduate and postgraduate teaching and training and is one of the teaching hospitals affiliated to the Ministry of Higher Education in the UAE. All 118 nurses working in the hospital were included in the study. All of the nurses (except 1 newly appointed nurse) had been professionally active for 1 year or more, in direct patient care and hospital hygiene. The hospital has a policy on use of standard precautions, and nurses receive training in standard precautions when they are hired.

A pre-tested, structured, anonymous, self-administered questionnaire was used to assess the nurses' awareness of and knowledge about standard precautions in addition to collecting sociodemographic information and their lifetime duration of clinical experience. This was a 12-item questionnaire with both open-ended and closed questions in English; it took 10-15 minutes to complete. The questionnaire was developed after a thorough review of the literature and was sent to 3 experts in public health to check for face and content validity. After revision, the questionnaire was piloted on a group of nurses who attended a breast cancer awareness programme and who were not included in the main study. Any necessary modifications were made.

Questionnaires were distrubuted to nurses by the nursing superintendant and were completed during their duty time. Before administration of the questionnaire, the purpose of the study was explained to each respondent and he/ she was assured about the confidentiality of the information. Informed consent for partipcation was obtained from each nurse.

The data from the questionnaire were coded and entered into a Microsoft Excel spreadsheet and analysis was done using SPSS, version 17. The chi-squared test was used to test the association between variables.

\section{Results}

All 101 nurses present on the day of the study agreed to participate: $10.9 \%$ males and $89.1 \%$ females (Table 1 ). The mean age of the respondents was 29.6 [standard deviation (SD) 6.0] years, range 19-48 years. Lifetime work experience varied between 10 months and 22 years. The mean duration of clinical experience was 79.4 (SD 50.3) months. Half of the respondents (51.5\%) had been professionally active for between 1 and 5 years.

Overall, 98 (97.0\%) nurses had heard about standard precautions; 3 had not, despite being in daily practice; all had professional experience $<5$ years.

The remainingknowledge questions were answered by those who were aware of standard precautions. Among them $51(52.0 \%)$ had obtained information about the concept of standard precaution from seminars and workshops, 31 (31.6\%) from classroom lectures given by their teachers and only 16 (16.3\%) got their knowledge of standard precautions from books.

Less than half the nurses (45.9\%) agreed that the aim of standard precautions was to protect both HCWs and 


\begin{tabular}{lcc}
\hline \multicolumn{3}{l}{$\begin{array}{l}\text { Table 1 Sociodemographic } \\
\text { characteristics of the nurses }\end{array}$} \\
$\begin{array}{l}\text { Ch= 101) } \\
\text { Characteristic }\end{array}$ & No. & $\%$ \\
$\begin{array}{l}\text { Age (years) } \\
\quad<25\end{array}$ & 11 & 10.9 \\
$25-29$ & 48 & 47.5 \\
$30-34$ & 24 & 23.8 \\
$35-39$ & 6 & 5.9 \\
$\geq 40$ & 12 & 11.9 \\
Sex & & \\
$\quad$ Male & 11 & 10.9 \\
$\quad$ Female & 90 & 89.1 \\
$\begin{array}{l}\text { Work experience } \\
\text { (years) }\end{array}$ & & \\
$\quad<5$ & 52 & 51.5 \\
5-10 & 33 & 32.7 \\
$>10$ & 16 & 15.8 \\
\hline
\end{tabular}

patients from transmission of infection (Table 2); 58.2\% thought that standard precautions were intended to protect HCWs from getting infections from patients. A quarter (25.5\%) agreed that standard precautions aimed to protect HCWs while handling infectious waste. All respondents knew the importance of $\mathrm{HBV}$ vaccination and all had been vaccinated.

With regard to knowledge about infectious blood and body fluids, $61.2 \%$ of nurses agreed that all patients were potentially infectious irrespective of their diagnostic status, $27.6 \%$ believed that only those diagnosed were infectious and $11.2 \%$ believed that those suspected of being infected are potentially infectious (Table 3).

Among those who had $<5$ years work experience, $63.3 \%$ agreed that all patients were potentially infectious; $75.0 \%$ of those with $>10$ years experience had correct knowledge of standard precautions guidelines (Table 3 ).

\section{Discussion}

Standard precautions are aimed at preventing transmission of infectious agents via blood and body fluids. A study conducted in western Algeria observed that lack of adherence to standard precautions was primarily due to lack of knowledge [15]. More than $97 \%$ of teaching hospital nurses in the present study had heard about standard/universal precautions. A study conducted among nurses in Nigeria observed that only $34.2 \%$ had heard about standard/universal precautions [16]. Kermode et al. conducted a study among HCWs in rural north India and observed that knowledge of standard precautions was correct among only $56 \%$ of respondents [17]. In a study among postgraduate nurses in Spain, a high degree of confusion and a lack of knowledge regarding standard precautions were observed [18].

Although almost all the nurses had heard of standard precautions, a much lower proportion (61.2\%) agreed that the blood and body fluids of all patients were potentially infectious irrespective of their diagnostic status, according to CDC guidelines [7]. The remainder thought that only diagnosed patients or only suspected cases should be considered potentially infectious.

In the current study, $58.2 \%$ of nurses believed that standard precautions are aimed at protecting HCWs from getting infections from patients, $23.5 \%$ thought they were to prevent patients getting infected from HCWs and $45.9 \%$ that they aimed to protect both HCWs as well as patients from infections. In a study among 82 nurses in a public hospital in Brazil, $11.0 \%$ understood standard precautions as protective measures for professionals only, $52.4 \%$ for both professionals and patients, $7.3 \%$ for patient care independent of the diagnosis, and $9.8 \%$ for patients with diagnosed infection [19]. Another study in Brazil had similar finding with regard to knowledge about standard precautions among nurses involved in pre-hospital care [12].

\section{Conclusion}

Although over $95 \%$ of nurses in this hospital in Ajman were aware of standard precautions, knowledge about standard precautions guidelines and their implementation was not up to standard.

\begin{tabular}{|c|c|c|c|c|c|c|c|c|}
\hline \multirow[t]{3}{*}{ Aims of standard precautions } & \multicolumn{6}{|c|}{ Work experience (years) } & \multirow{2}{*}{\multicolumn{2}{|c|}{$\begin{array}{c}\text { Total } \\
(n=98)^{\mathrm{a}}\end{array}$}} \\
\hline & \multicolumn{2}{|c|}{$\begin{array}{c}<5 \\
(n=49)^{\mathrm{a}}\end{array}$} & \multicolumn{2}{|c|}{$\begin{array}{c}5-10 \\
(n=33)\end{array}$} & \multicolumn{2}{|c|}{$\begin{array}{c}>10 \\
(n=16)\end{array}$} & & \\
\hline & No. & $\%$ & No. & $\%$ & No. & $\%$ & No. & $\%$ \\
\hline Protect HCWs & 29 & 59.2 & 17 & 51.5 & 11 & 68.8 & 57 & 58.2 \\
\hline Protect patients getting infected from HCWs & 14 & 28.6 & 6 & 18.2 & 3 & 18.3 & 23 & 23.5 \\
\hline Prevent mutual transfer of infection & 22 & 44.9 & 16 & 48.5 & 7 & 43.8 & 45 & 45.9 \\
\hline Protect HCWs while handling infectious waste & 12 & 24.5 & 9 & 27.3 & 4 & 25.0 & 25 & 25.5 \\
\hline Protect HCWs while handling sharp waste & 11 & 22.4 & 7 & 21.2 & 4 & 25.0 & 22 & 22.4 \\
\hline
\end{tabular}

Total exceeds $100 \%$ due to multiple answers.

${ }^{a} 3$ nurses were unaware of standard precautions.

HCWs = health care workers. 


\begin{tabular}{|c|c|c|c|c|c|c|c|c|}
\hline \multirow{3}{*}{$\begin{array}{l}\text { Potentially infectious blood } \\
\text { and body fluids }\end{array}$} & \multicolumn{6}{|c|}{ Work experience (years) } & \multirow{2}{*}{\multicolumn{2}{|c|}{$\begin{array}{c}\text { Total } \\
(n=98)\end{array}$}} \\
\hline & \multicolumn{2}{|c|}{$\begin{array}{c}\quad<5 \\
(n=49)\end{array}$} & \multicolumn{2}{|c|}{$\begin{array}{c}5-10 \\
(n=33)\end{array}$} & \multicolumn{2}{|c|}{$\begin{array}{l}>10 \\
(n=16)\end{array}$} & & \\
\hline & No. & $\%$ & No. & $\%$ & No. & $\%$ & No. & $\%$ \\
\hline All patients & 31 & 63.3 & 17 & 51.5 & 12 & 75.0 & 60 & 61.2 \\
\hline $\begin{array}{l}\text { Only those diagnosed as } \\
\text { infectious }\end{array}$ & 12 & 24.5 & 12 & 36.4 & 3 & 18.8 & 27 & 27.6 \\
\hline Those suspected & 6 & 12.2 & 4 & 12.1 & 1 & 6.3 & 11 & 11.2 \\
\hline
\end{tabular}

The findings of this study highlight the need to implement a programme to improve knowledge on standard precautions.

\section{Acknowledgements}

We gratefully acknowledge the participation of all the nurses, without whose contribution the study would not have been completed.

The official support from the university is also acknowledged.

\section{References}

1. Gerberding JL. Incidence and prevalence of human immunodeficiency virus, hepatitis B virus, hepatitis $C$ virus, and cytomegalovirus among health care personnel at risk for blood exposure: final report from a longitudinal study. Journal of Infectious Diseases, 1994, 170:1410-1417.

2. Ramos-Gomez F et al. Accidental exposures to blood and body fluids among health care workers in dental teaching clinics: a prospective study. Journal of the American Dental Association, 1997, 128:1253-1261.

3. Ruben FL et al. Epidemiology of accidental needle-puncture wounds in hospital workers. American Journal of the Medical Sciences, 1983, 286:26-30.

4. Pruss-Üstün A, Rapiti E, Hutin Y. Sharps injuries: global burden of disease from sharps injuries to health-care workers. Geneva, World Health Organization, 2003.

5. The world health report 2002: reducing risks, promoting health life. Geneva, World Health Organization, 2002.

6. Mizuno $\mathrm{Y}$ et al. Study of needlestick accidents and hepatitis $\mathrm{C}$ virus infection in healthcare workers by molecular evolutionary analysis. Journal of Hospital Infection, 1997, 35:149-154.

7. Update: universal precautions for prevention of transmission of human immunodeficiency virus, hepatitis B virus, and other bloodborne pathogens in health-care settings. Morbidity and Mortality Weekly Report, 1988, 37(24):377-388.

8. Chan R et al. Nurses' knowledge of and compliance with universal precautions in an acute care hospital. International Journal of Nursing Studies, 2002, 39:157-163.

9. Gershon RR et al. Compliance with universal precautions among health care workers at three regional hospitals. American Journal of Infection Control, 1995, 23(4):225-236.

10. Michalsen A et al. Compliance with universal precautions among physicians. Journal of Occupational and Environmental Medicine, 1977, 39(2):130-137.
11. Ofili AN, Asuzu MC, Okojie OH. Knowledge and practice of universal precautions among nurses in central hospital, BeninCity, Edo State, Nigeria. Nigerian Postgraduate Medical Journal, 2003, 10:26-31.

12. Oliveria AC et al. Knowledge and attitude regarding standard precautions in a Brazilian public emergency service: a cross sectional study. Revista da Escola de Enfermagem da USP, 2009, 43(2):313-319.

13. Askarian M, McLaws ML, Meylan M. Knowledge, attitude and practices related to standard precautions of surgeons and physicians in university-affiliated hospitals of Shiraz, Iran. International Journal of Infectious Diseases, 2007, 11(3):213-219.

14. Jeong I, Cho J, Park S. Compliance with standard precautions among operating room nurses in South Korea. American Journal of Infection Control, 2008, 36:739-742.

15. Beghdadli B et al. Respect des "précautions standards" par le personnel infirmier d'un centre hospitalo-universitaire de l'ouest algérien ["Standard precautions" practices among nurses in a university hospital in Western Algeria]. Sante Publique, 2008, 20:445-453.

16. Ofili AN. Asuzu MC, Okojie OH. Knowledge and practice of Universal Precautions among nuses incentral hospital, Benincity, Edo State, Nigeria. Nigerian Postgraduate Medical Journal, 2003, 10:26-31.

17. Kermode $\mathrm{M}$ et al. Compliance with Universal/Standard Precautions among health care workers in rural north India. American Journal of Infection Control, 2005, 33:27-33.

18. López $\mathrm{C}$ et al. Standard precautions: are these known? Are they applied? Revista de Enfermeria (Barcelona, Spain), 2006, 29:16-20.

19. Melo Dde $S$ et al. Nurses' understanding of standard precautions at a public hospital in Goiania-GO, Brazil. Revista LatinoAmericana de Enfermagem, 2006, 14:720-727. 